\title{
Short communication \\ The Outbreak of the COVID-19 Pandemic and its Healing Effects on the Environment
}

\author{
MARISELVAM AMMASI KRISHNAN ${ }^{1 *}$, MUTHU RAM PAZHANI SELVAM KAVITHA ${ }^{1}$, \\ PRAKASH VEERASAMY RADHAKRISHNAN ${ }^{2}$, MURUGESAN GURUSAMY ${ }^{3}$ \\ ${ }^{1}$ Department of Applied Science and Technology, Anna University, Chennai, Tamil Nadu, India, 600025 \\ ${ }^{2}$ Department of Electronics and Communication Engineering, Hindustan Institute of Technology and Science Chennai, \\ Tamilnadu \\ ${ }^{3}$ Department of Electronics and Communication Engineering, Anjalai Ammal Mahalingam Engineering College, Kovilvenni, \\ Thiruvarur, 614403
}

Abstract. COVID 19, the virus which originated from a wet market in Wuhan, China. Since its exposure in December, 2019, the virus has spread to almost all the countries in the world, thus turning an epidemic into a pandemic. Although COVID 19 has taken a massive toll on the Human health and global economy, its outbreak has shown positive impacts on the environmental air quality. As the majority of the world is under lock down, the global air pollution has reduced by 40 percent during April 2020. This was identified with the assistance of the data collected from European and American Atmospheric monitoring sites. This article thus summarizes the positive effects of lock down and reduced human mobility, towards the improvement of environmental air quality.

Keywords: COVID-19, pandemic, $\mathrm{NO}_{2}$, air quality

\section{Introduction}

In late December 2019, a contagious disease of the family coronavirus was detected in Wuhan, China, which was later named COVID-19. Shortly, human to human transfer was declared by the World Health Organization (WHO, 2020). In the later part of the month of January 2020, numerous cases of COVID 19 started to appear in Wuhan, China and it broke out into a worldwide pandemic within a short span [1]. To mitigate the further spread of this virus outbreak, Wuhan was quarantined on 23rd January 2020 which lasted for 45 days [2]. Soon after, Hubei Province went under lock down. Chinese Government closed all the spots of social gathering across the whole province. During February 2020, new epicenters of the virus started to begin at Countries such as the USA, Italy, Spain, France and the UK. The virus started to spread at a faster rate in these countries than the actual starting point of the virus [3]. The Act of Social gathering of people was accused for the large-scale outbreak of the virus. Transportation across the countries was the major reason for the transformation of an epidemic into a pandemic. Most people globally visited the majority of the places in China during the last week of January 2020 as the country celebrated its Lunar new year on 25th January 2020. This added fuel to the fire. Almost 17 million flight movements occurred both into and away from China during the months of January and February 2020 [4]. The First cases of Spain, Italy, UK, France and India were reported in Mid-February, while the USA dates back its first case to the starting of March. As of May 5th 2020, COVID 19 has shown its havoc on humanity by infecting 36 million people and taking a death toll of more than 2.5 million and still rising in more than 190 countries [5]. These numbers are still rising amidst the lock down that all the nations have applied. Due to this worldwide lockdown, most of the manufacturing sectors and public transportation departments across the globe have been severely affected [6]. This has not only occurred in developed countries but also in the developing countries such as India. While the whole world was discussing one of the greatest economic falls of all times and the terror of COVID 19, the virus helped the Earth heal itself off the anthropogenic air pollution.

*email: mariselvamak@gmail.com 
Surprisingly, the reduction in human activities helped to improve the air quality over the globe.

Form Figure 1, the decrease in the $\mathrm{NO}_{2}$ levels can be visualized for various countries, evidently due to partial lock down throughout the world due to COVID 19 onset. The comparison was between the period of two months (March and April) for the years 2019 and 2020. This was done in order to cancel out the climatic factors as the study period of both the years being same with same climatic conditions. Table 1 mentions the average percent reduction in $\mathrm{NO}_{2}$ concentration and the concentrations before and after the lockdown was imposed.

\section{Assessment of $\mathrm{NO}_{\mathrm{x}}$ pollution during COVID 19 lockdown}

Table 1. Details of the data on emissions in different countries

\begin{tabular}{|c|c|c|c|c|}
\hline Country & $\begin{array}{c}\text { Mean NO} \text { levels } \\
\text { During March April- } \\
2019\end{array}$ & $\begin{array}{c}\text { Mean } \mathrm{NO}_{2} \text { levels } \\
\text { During March April- } \\
2020\end{array}$ & $\begin{array}{c}\text { Reduction } \\
\text { percentage in } \mathrm{NO}_{2} \\
\text { levels }\end{array}$ & Source \\
\hline USA & $52.9 \mu \mathrm{g} / \mathrm{m}^{3}$ & $31.74 \mu \mathrm{g} / \mathrm{m}^{3}$ & $40 \%$ & NASA,2020[7] \\
Italy & $65 \mu \mathrm{g} / \mathrm{m}^{3}$ & $35 \mu \mathrm{g} / \mathrm{m}^{3}$ & $47 \%$ & ESA,2020 [8] \\
Spain & $42.4 \mu \mathrm{g} / \mathrm{m}^{3}$ & $20.6 \mu \mathrm{g} / \mathrm{m}^{3}$ & $51 \%$ & ESA,2020 \\
France & $83 \mu \mathrm{g} / \mathrm{m}^{3}$ & $36.52 \mu \mathrm{g} / \mathrm{m}^{3}$ & $54 \%$ & ESA,2020 \\
UK & $24 \mu \mathrm{g} / \mathrm{m}^{3}$ & $18 \mu \mathrm{g} / \mathrm{m}^{3}$ & $25 \%$ & ESA,2020 \\
India & $139 \mu \mathrm{g} / \mathrm{m}^{3}$ & $84 \mu \mathrm{g} / \mathrm{m}^{3}$ & $40 \%$ & ESA,2020 \\
\hline
\end{tabular}

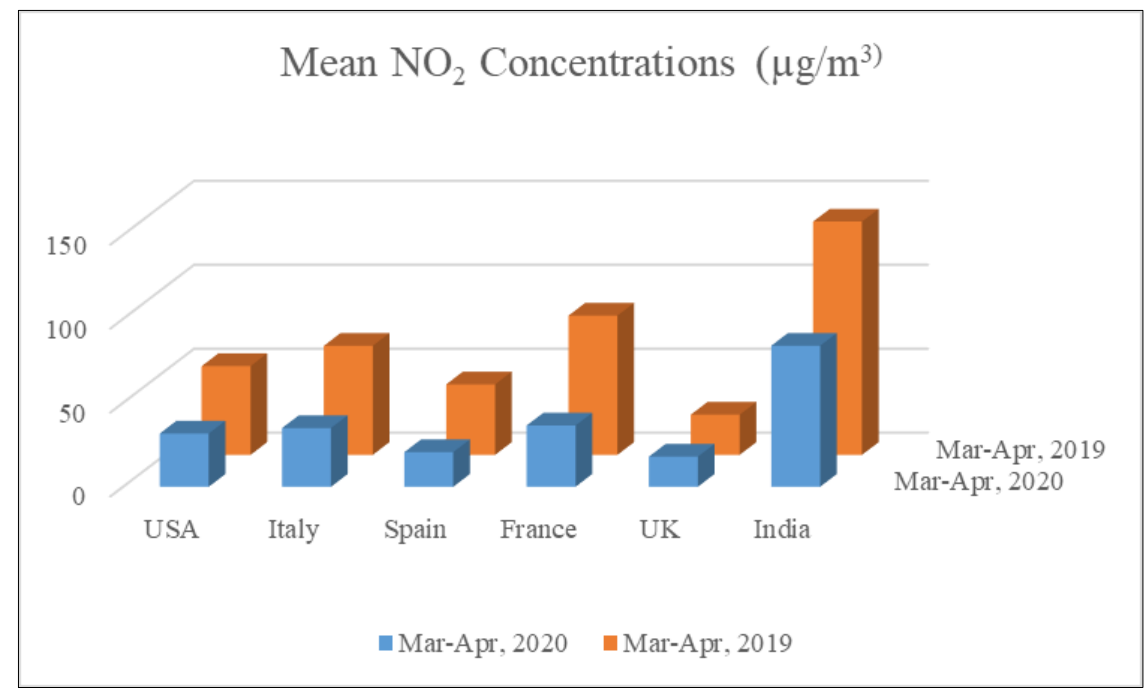

Figure 1. Comparison of $\mathrm{NO}_{2}$ levels of different countries (Brown bars indicate March - April 2019 values and Blue bars are for the same periods during next years)

NOx (Nitrogen dioxide) is a highly responsive pollutant which is generated from automobile combustion in specific. Transport pollution is seen as the primary means of $\mathrm{NO}_{2}$ liberation [9]. The yearly death rate due to Air pollution as per World Health Organization is roughly around 4.2 million [10]. Although COVID 19 had its negative impact on the world economy, its positive effect on the reduced global air pollution cannot be gone unnoticed. Table 2 shows mobility indexes of different parts of the world.

The pollution levels are much lower during the lockdown period due to reduced vehicular emission and it exerted a significant positive impact on the environment. A variety of studies is going on the basis of improving Air quality across all the parts of the World. National Aeronautics and Space Administration (NASA) and European Space Agency (ESA) use higher end monitoring methods to 
constantly monitor the Air Quality. $\mathrm{NO}_{2}$ levels in the air are monitored by Aura Satellite with the help of Ozone Measuring Instrument (OMI) and Sentinel 5P Satellite using Tropospheric Monitoring Instrument.

Table 2. Mobility index table

\begin{tabular}{|c|c|c|c|c|c|c|}
\hline Country & Transport & $\begin{array}{c}\text { Grocery and } \\
\text { Pharmacy }\end{array}$ & $\begin{array}{c}\text { Retail and } \\
\text { Recreation }\end{array}$ & Work place & $\begin{array}{c}\text { Parks and } \\
\text { Outings }\end{array}$ & Residential \\
\hline USA & $-48 \%$ & $-16 \%$ & $-42 \%$ & $-36 \%$ & $-11 \%$ & $+11 \%$ \\
Italy & $-81 \%$ & $-74 \%$ & $-92 \%$ & $-54 \%$ & $-85 \%$ & $+22 \%$ \\
France & $-77 \%$ & $-58 \%$ & $-83 \%$ & $-43 \%$ & $-68 \%$ & $+16 \%$ \\
Spain & $-82 \%$ & $-66 \%$ & $-92 \%$ & $-62 \%$ & $-77 \%$ & $+21 \%$ \\
UK & $-64 \%$ & $-37 \%$ & $-78 \%$ & $-48 \%$ & $-10 \%$ & $+14 \%$ \\
India & $-66 \%$ & $-51 \%$ & $-86 \%$ & $-41 \%$ & $-68 \%$ & $-22 \%$ \\
Turkey & $-88 \%$ & $-82 \%$ & $-91 \%$ & $-63 \%$ & $-75 \%$ & $+23 \%$ \\
Argentina & $-72 \%$ & $-52 \%$ & $-88 \%$ & $-47 \%$ & $-95 \%$ & $+25 \%$ \\
\hline
\end{tabular}

Google Tracking Data is used to come to a conclusion on the mobility of the people towards different works and also to confirm that the pollution levels have reduced during the times when the transportation has reduced. Data proves that on average, transportation has reduced by $80 \%$, which was $90 \%$ between February and March 2020. Some of the countries such as Turkey and Argentina also showed a high reduction in the usage of public transportation.

\section{United States of America}

After the pandemic spread violently, the USA became the epicenter of the virus. Soon after, the lockdown was announced on 15th March 2020[11]. Figure 2 shows the comparative OMI image over southeast parts of the USA and Florida before and after a month of lockdown. Figure 2a shows for the previous year red color indicating high level of pollution whereas figure $2 \mathrm{~b}$ shows no red color at all. Likewise figure $\mathrm{c}$ and figure $\mathrm{d}$ are similarly distinguishable. The red grade indicates $41 \times 10^{-6} \mathrm{~mole} / \mathrm{cm}^{2}$ of image surface. The Data reveals that there is a $40 \%$ reduction in the atmospheric $\mathrm{NO}_{2}$ content [7]. Also, during this time, only about $50 \%$ of the transportation was online in the USA.

\section{Italy}

The rate of death in Italy was very high in the beginning. A lockdown was proposed over the country of Italy on 9th March 2020 [12]. Due to continuous lockdown, the country experienced a reduction in the atmospheric $\mathrm{NO}_{2}$ by $47 \%$ [8]. Figure 3 shows the comparison of the $\mathrm{NO}_{2}$ levels just after lockdown and two weeks after the imposition of lockdown. During this time, the reduction in usage of transport accounted for $81 \%$. Units of color levels showing gradation are almost $120 \mu \mathrm{mol} / \mathrm{cm}^{2}$ of image surface.

\section{Spain}

Figure 3 shows the TROPOMI image comparison of the Satellite image of $\mathrm{NO}_{2}$ over the country of Spain during the period of 13th March to 13th April. Lockdown was imposed in the country on 15th March [13]. The transportation reduction also was recorded as $82 \%$ during the third week of April. During this period the $\mathrm{NO}_{2}$ in the air reduced by $51 \%$ [8]. Thus, it is satisfactory to say that air pollution levels have reduced during COVID 19 in Spain. It may noted that Spain is less affected than Italy. 


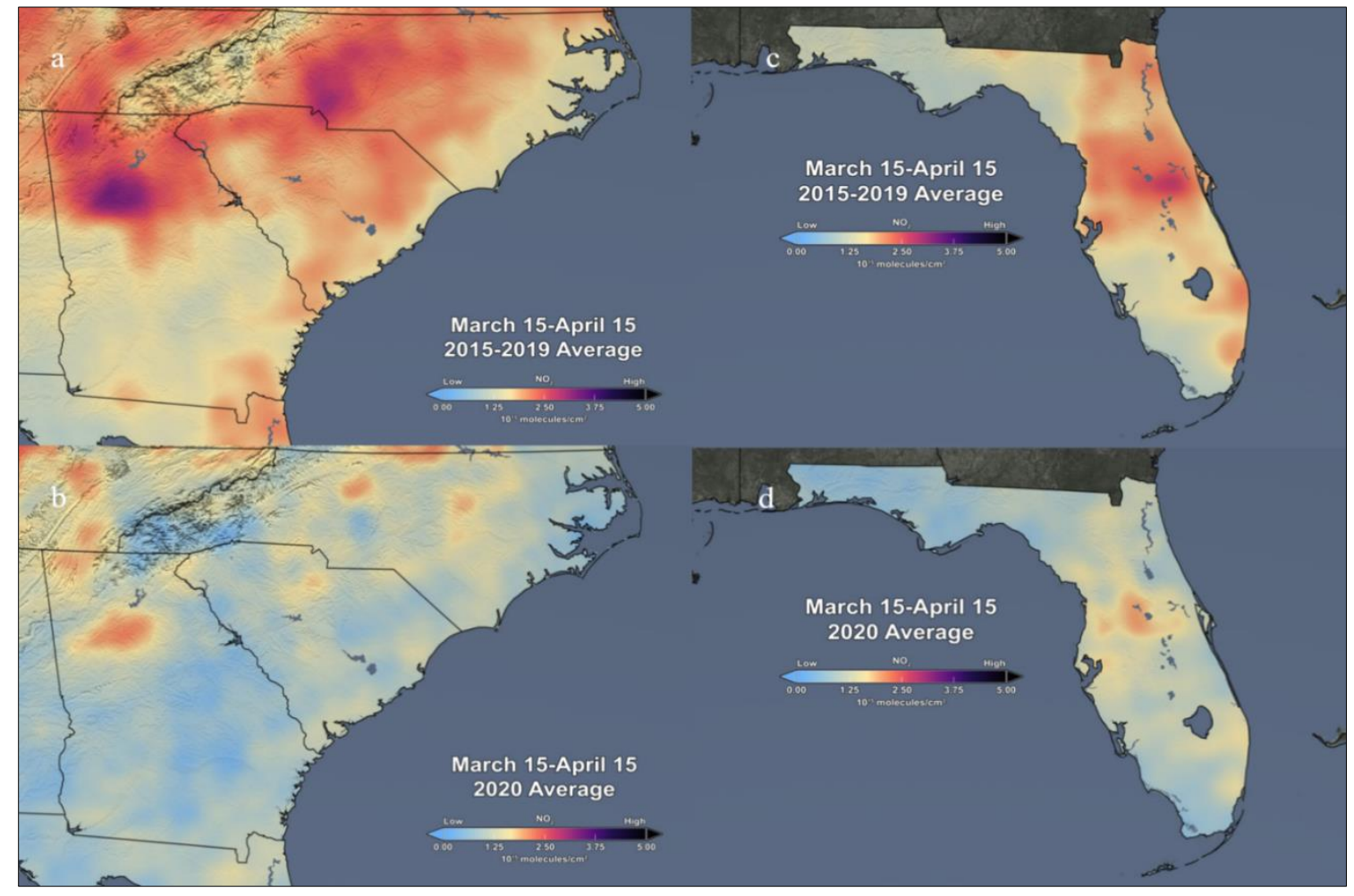

Figure 2. OMI image produced by Aura satellite comparing the $\mathrm{NO}_{2}$ levels over the air during a) March - April 2015 to 2019 and b) March - April 2020 (Over southeastern Part of USA) c) and d) Same periods over Florida (The color bars indicate the gradation of pollution).

(Courtesy NASA, 2020)

\section{France}

The virus also spread at a faster rate in France. To control the deadly outbreak of the virus, the French Government had to lock the entire country from 17th March 2020 [12]. From that particular point of time, the atmospheric pollution levels of $\mathrm{NO}_{2}$ reduced by a margin of 54\% [8]. Almost $77 \%$ of the country's Transportation was at a halt during this period, thus providing a satisfactory record to prove the positive impact of COVID 19 on Earth. If the lock down condition have not been as severe as in Italy. The pollution level has not reduced very much from 2019 to 2020.

\section{UK}

The Virus started spreading in the United Kingdom later than the other three countries, but the spreading gathered speed at once. So, the lockdown was imposed over the country on 23rd March, a week later than most of the countries [14]. From that period, the UK experienced a reduction in transportation via automobiles up to $70 \%$. On April 26th the reduction in usage of transport was $64 \%$. This provided an improved air quality over the UK, which had almost $25 \%$ less $\mathrm{NO}_{2}$ than the air that was present in the previous year's [8] as can be seen from Figure 4. 


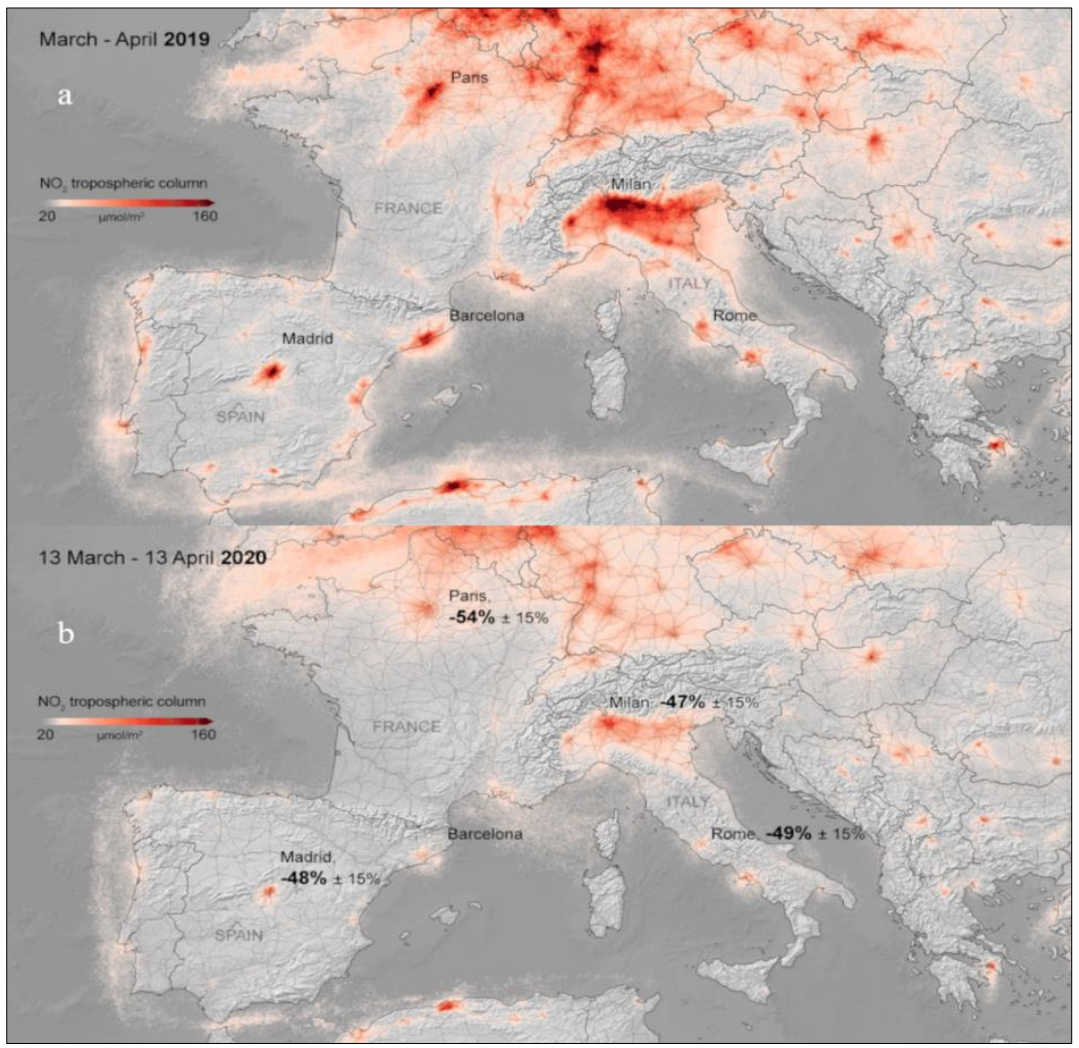

Figure 3. TROPOMI image comparison of $\mathrm{NO}_{2}$ levels in air over the Countries of Spain, Italy, and France during a) March - April 2019 and b) March - April 2020. (Courtesy ESA, 2020)

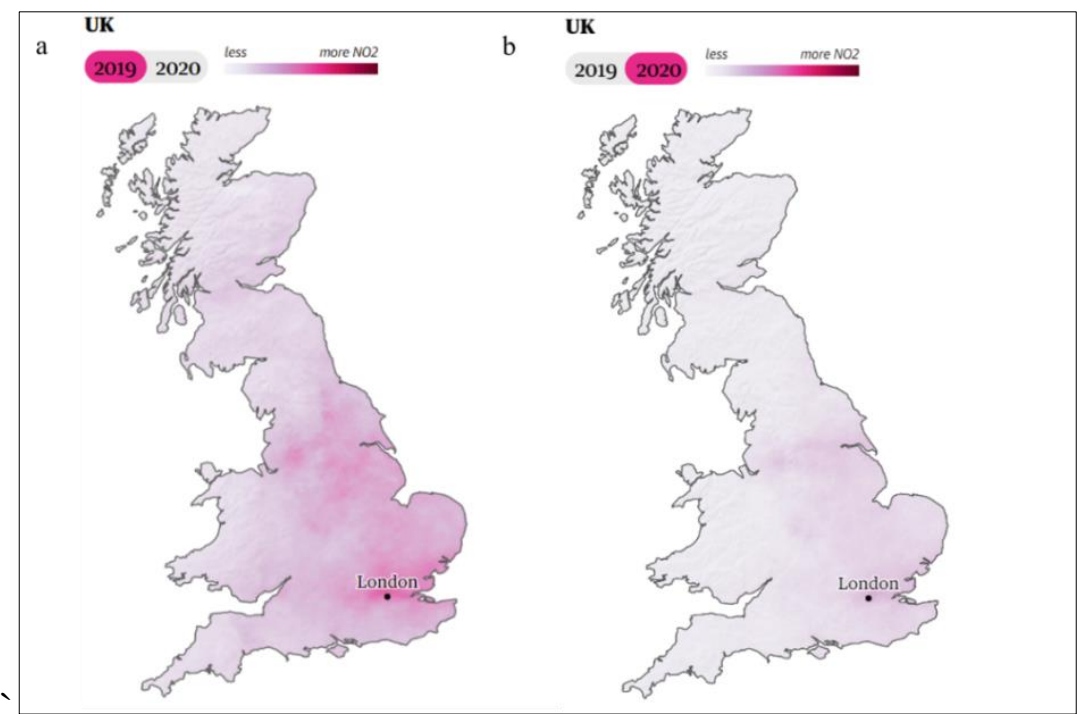

Figure 4. Sentinel 5P satellite image of the United Kingdom comparing the $\mathrm{NO}_{2}$ levels during the time period of 15th March to 15 th April (a) 2019 and (b)2020

The reduction level dropped considerably as shown by the absence of red color on the south eastern side in United Kingdom (Figure 4). 


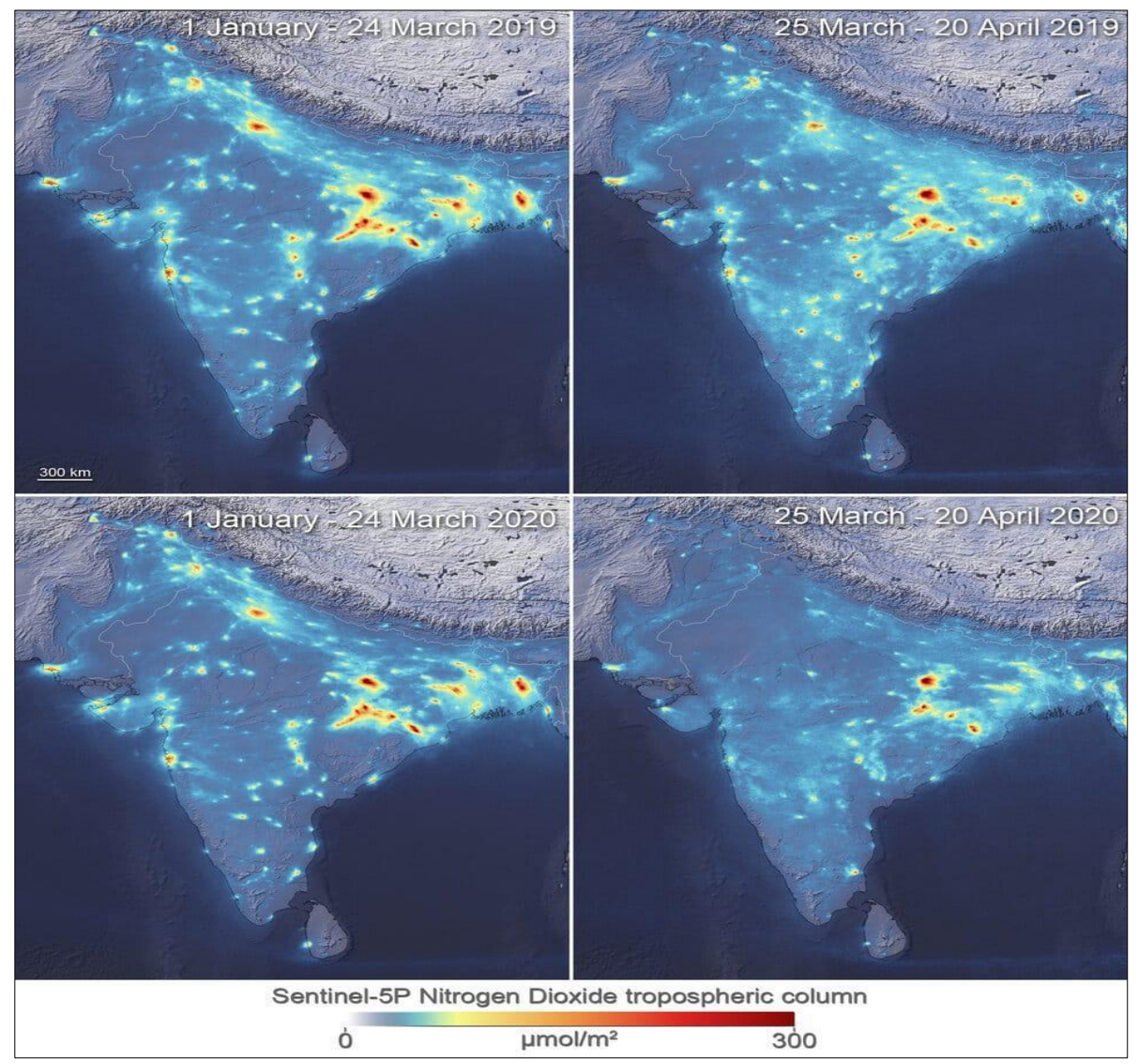

Figure 5. Satellite image of $\mathrm{NO}_{2}$ pollutants over Indian Sub-Continent over different time periods from January 2019 to April 2020. (Courtesy ESA, 2020)

\section{India}

India is a country which started very late in spreading., It had more than 50,000 COVID 19 cases [10]. The air pollution was high from 13th March to 24th March 2020 as most of the people were trying to return to their homes. That increased the pollution a fair amount. To prevent the social spreading of the virus, the whole subcontinent was brought under lockdown on 25th March [15]. From then, within a span of one month, the pollution level of $\mathrm{NO}_{2}$ due to vehicular emissions was reduced by as high as $40 \%$ [16] as the public transport was effectively brought to a halt with $66 \%$ of the people not using their automobiles. The result can be seen as a satellite image as shown in Figure 5. Thus, India's air pollution levels were reduced due to lockdown following the outbreak of COVID 19. India's $\mathrm{NO}_{2}$ level is shown to be $160 \mu \mathrm{mol} / \mathrm{cm}^{2}$ as a maximum in red color only in certain regions. South India has very much less $\mathrm{NO}_{2}$ levels as shown by green color, about $20 \mu \mathrm{mol} / \mathrm{cm}^{2}$.

\section{Conclusions}

Although COVID 19 has its firm grip over the health of the human race and its economy, the fact that the consequences of the outbreak of the pandemic has allowed and has given a chance for the planet to heal itself cannot be rejected. COVID 19 also displayed to us the ability of the Earth to heal itself when untouched which marks a very important occurrence in human history that there still might be a chance left for us to repair the environment, preserve it, and live in a healthy world. These facts can be used by regulatory bodies to further tighten up the standards or by the governments to manage the activities of the industrial and automobile sectors to achieve and sustain better air quality. 


\section{References}

1. DUTHEIL, F., BAKER, J.S., NAVEL, V., COVID-19 as a factor influencing air pollution? Environ. Pollut. 263, 2020, 2019-2021. https://doi.org/10.1016/j.envpol.2020.114466.

2.WILDER-SMITH, A., FREEDMAN, D.O., Isolation, quarantine, social distancing and community containment: Pivotal role for old-style public health measures in the novel coronavirus (2019-nCoV) outbreak. J. Travel Med. 27, 2020, 1-4. https://doi.org/10.1093/jtm/taaa020

3.MUHAMMAD, S., LONG, X., SALMAN, M., COVID-19 pandemic and environmental pollution: A blessing in disguise? Sci. Total Environ. 728, 2020, 138820.

https://doi.org/10.1016/j.scitotenv.2020.138820

4.***IATA. (2020). Retrieved from IATA: https://www.transportation.gov/airconsumer

5.***Worldometer. (2020, April). Retrived from Worldometer:

https://www.worldometers.info/ coronavirus/

6.NICOLA, M., ALSAFI, Z., SOHRABI, C., KERWAN, A., AL-JABIR, A., IOSIFIDIS, C., AGHA, M., AGHA, R., 2020. The Socio-Economic Implications of the Coronavirus and COVID-19 Pandemic: A Review, International Journal of Surgery. IJS Publishing Group Ltd.

https://doi.org/10.1016/j.ijsu.2020.04.018

7.***NASA. (2020). NASA. Retrieved from https://www.nasa.gov/feature/nasa-monitors-environmental- signals-from-global-response-to-covid-19/

8.***ESA. (2020). Retrieved from ESA:

https://www.esa.int/About_Us/Corporate_news/ESA_in_a_post-COVID_world.

9.TEZEL, M.N., SARI, D., OZKURT, N., KESKIN, S.S., Combined NOx and noise pollution from road traffic in Trabzon, Turkey. Sci. Total Environ. 696, 2019,134044.

https://doi.org/10.1016/j.scitotenv.2019.134044

10.***WHO. (2020). Retrieved from WHO:

https://www.who.int/emergencies/diseases/novel-coronavirus -2019

11.***USATODAY. (2020, April). Retrieved from USATODAY:

https://www.usatoday.com/story/opinion/2020/03/21/coronavirus-america-needs-five-week-national-

lockdown-column/2890376001/

12.***Bloomberg. (2020, April). Retrieved from Bloomberg:

https://www.bloomberg.com/news/articles/2020-05-04/conte-faces-surge-of-lockdown-criticism-withitaly-set-to-reopen

13.***EXPRESS. (2020, April). Retrieved from EXPRESS.CO.UK:

https://www.express.co.uk/travel/articles/1258343/spain-lockdown-how-long-is-spain-lockdown-

timeframe-madrid-coronavirus

14.***HEART.CO.UK. (2020, April). Retrieved from HEART.CO.UK:

https://www.heart.co.uk/news/how-long-uk-lockdown-last/

15.HINDU, T. (2020, May). Retrieved from THE HINDU: https://www.heart.co.uk/news/how-long-uklockdown-last/

16.TIMES, T. E. (2020, May). Retrieved from THE ECONOMIC TIMES:

https://economictimes.indiatimes.com/news/politics-and-nation/lockdown-major-air-pollutants-pm2-5pm10-and-nox-down-by-at-least-50-in-delhi/articleshow/75028184.cms

Manuscript received: 27.12 .2021 